\title{
Clinical and biochemical prediction of early fatal outcome following hip fracture in the elderly
}

\author{
Ove Talsnes • Fredrik Hjelmstedt • Ola E. Dahl • \\ Are Hugo Pripp • Olav Reikerås
}

Received: 10 September 2010 / Revised: 22 October 2010 /Accepted: 22 October 2010 /Published online: 16 November 2010

(C) The Author(s) 2010. This article is published with open access at Springerlink.com

\begin{abstract}
Hip fracture, a moderate musculoskeletal trauma, is associated with a high postoperative mortality. Most patients are elderly, with comorbid conditions and often with heart disease. The objective of this study was to find out if clinical parameters and analyses of specific muscle enzymes could predict three month postoperative mortality. A total of 302 patients above 75 years of age with hip fracture were consecutively enrolled. Baseline information on age, sex and comorbidity assessed with the American Society of Anesthesiologists (ASA) score was obtained before surgery. Creatine kinase (CK), myocardium-specific creatine kinase $(\mathrm{CK}-\mathrm{MB})$ and troponin $\mathrm{T}(\mathrm{TnT})$ were analysed from venous blood, collected the day before surgery $(-1)$ and postoperatively, within 24 hours $(0)$ and on days one $(+1)$ and four $(+4)$. The overall three month mortality was $19.5 \%$. Multivariate analyses showed that
\end{abstract}

O. Talsnes $(\bowtie) \cdot$ O. E. Dahl

Department of Orthopaedics, Elverum Central Hospital,

Elverum, Norway

e-mail: ove.talsnes@sykehuset-innlandet.no

F. Hjelmstedt

Department of Orthopaedics, Buskerud Central Hospital,

Drammen, Norway

O. E. Dahl

Thrombosis Research Institute,

London, UK

\section{A. H. Pripp}

Biostatistics and Epidemiology Unit, Oslo University Hospital, Oslo, Norway

O. Reikerås

Department of Orthopaedics, Oslo University Hospital,

Oslo, Norway age, male sex and comorbidity (ASA) correlated with mortality ( $p=0.027, p=0.002, p<0.001$, respectively). Surgery induced a two- to threefold increase of CK and CK-MB but without any correlation with mortality. However, high TnT levels $>0.04 \mu \mathrm{g} / 1$ correlated significantly with death (days $-1,+1$ and $+4, p=0.003, p=0.005$ and $p=0.003$, respectively). Multivariate analyses, adjusted for age, sex and ASA category, confirmed this correlation (day $+4, p=0.008$ ). Thus, in elderly patients with comorbidities undergoing hip fracture surgery information on sex, age, ASA category and postoperative laboratory analyses on $\mathrm{TnT}$ provide the clinicians with useful information on patients at risk of fatal outcome.

\section{Introduction}

Hip fracture is a moderate musculoskeletal trauma that mainly affects the older population with comorbid conditions. The number will increase markedly in coming years due to the ageing of the population [1]. Comorbidity and the double trauma may dispose them to serious postoperative adverse outcomes and a high mortality dominated by cardiovascular events [2-5]. Myocardial injury may be difficult to diagnose because of impaired communication, limitations of clinical manifestation and non-specific electrocardiographic (ECG) changes [6,7]. The isoenzyme myocardium-specific creatine kinase (CK-MB) is expressed in the myocardium and $\mathrm{CK}$ in the skeletal muscle cells. These two enzymes have traditionally been analysed in plasma to distinguish myocardial injury and skeletal muscle injury $[8,9]$. Troponins have been shown to be more specific and sensitive to cardiac injury $[10,11]$. Increased plasma levels of troponin have also been reported in pulmonary 
embolism, septicaemia and following major orthopaedic and cardiac surgery. In those conditions high plasma troponin levels have been associated with severe adverse outcomes and increased mortality [7, 12-15].

In this study we wanted to test the hypothesis that fatal outcome following hip fracture is not related to cardiomuscular plasma enzymes.

\section{Materials and methods}

The study was approved by the Regional Ethics Committee and National Medical Authorities and conducted in accordance with the Helsinki declaration.

A total of 302 consecutive patients over 75 years of age with dislocated hip fractures were enrolled in the study at Elverum $(\mathrm{ECH})$ and Buskerud $(\mathrm{BCH})$ central hospitals during the period 2005-2009. Comorbidity was routinely assessed according to the classification of the American Society of Anesthesiologists (ASA) [16]. All patients received loco-regional analgesia. A hemiprosthesis was inserted through a lateral incision and fixed with or without bone cement (Landos Titan or Landos Corail, DePuy, Warsaw, IN, USA).

Thromboprophylaxis (low molecular weight heparins) was administered routinely preoperatively (on hospital admission) with dalteparin 5000 IU s.c. (ECH) or enoxaparin $40 \mathrm{mgs.c}$. $(\mathrm{BCH})$ and subsequently once daily for about one week.

Blood samples were obtained from an antecubital vein, collected preoperatively $(-1)$ and postoperatively [within 24 hours $(0)]$ and on days one [24-48 h (+1)] and four $(+4)$. The blood samples were immediately processed and analysed according to local laboratory routines. Troponin $\mathrm{T}(\mathrm{TnT})$ and $\mathrm{CK}-\mathrm{MB}$ were measured by electrochemiluminescence immunoassay (ELICA, Roche, Basel, Switzerland and Abbott, Abbott Park, IL, USA). CK was measured by absorption photometry (Roche, Basel, Switzerland and Abbott, Abbott Park, IL, USA). Values for TnT were only measured at the ECH study centre $(n=146)$.

Descriptive statistics were mean and standard deviation if not otherwise stated. Differences between mortality groups were tested using a two-sample $t$ test or chi-square test for continuous or categorical data, respectively. Nonparametric Mann-Whitney tests were done for TnT due to skewed distribution. A linear mixed model for repeated measurements with a random intercept and Bonferroni adjusted pairwise post hoc comparisons were used to analyse the biochemical markers with respect to mortality and repeated venous blood analyses. Univariate and stepwise multivariate logistic regression analyses were used to estimate unadjusted and adjusted odds ratios with respect to survival at the three month follow-up. Results from multivariate logistic regression were based on models including only significant terms from stepwise regression to maximise the number of patients included. Missing data were assumed to be completely at random. The significance level was set to $p<0.05$.

\section{Results}

Demographic and clinical characteristics of patients are shown in Table 1. There were 229 women and 72 men, with a mean age of 84.7 (SD 5.1) and 83.7 (SD 4.7) years, respectively. By three months, 59 of 302 (19.5\%) had died, $62 \%$ women and $38 \%$ men.

ASA, male sex and age were significantly associated with mortality within three months (Table 1).

Within one day after surgery, the plasma levels of CK and CK-MB increased nearly threefold (inverse for the ratio). On days -1 and $+1, \mathrm{CK}$ and $\mathrm{CK}-\mathrm{MB}$ values were significantly higher among those who died compared to those who survived ( $p=0.001$ and $p=0.031$, respectively) (Fig. 1). On the fourth postoperative day, TnT plasma levels rose twofold in the mortality group and remained unchanged in the alive group. The plasma levels were significantly higher $(p<0.05)$ in the mortality group at all sampling times except at day 0 (Fig. 1)

Table 1 Demographic and clinical characteristics of patients at 3month follow-up

\begin{tabular}{llll}
\hline Characteristics & $\begin{array}{l}\text { Alive } \\
(n=243)\end{array}$ & $\begin{array}{l}\text { Dead } \\
(n=59)\end{array}$ & $p$ values \\
\hline $\begin{array}{l}\text { Age, years (mean } \pm \text { SD) } \\
\text { Sex }\end{array}$ & $84.1(5.1)$ & $86.2(4.6)$ & 0.004 \\
Female & $193(79.4 \%)$ & $37(62.7 \%)$ & 0.005 \\
Male & $50(20.6 \%)$ & $22(37.3 \%)$ & \\
Mobility & & & \\
Not mobile & $37(15.8 \%)$ & $10(17.2 \%)$ & 0.109 \\
Living aid & $23(9.8 \%)$ & $5(8.6 \%)$ & \\
Crutches & $51(21.8 \%)$ & $21(36.2 \%)$ & \\
No aid & $123(52.6 \%)$ & $22(37.9 \%)$ & \\
ASA score & & & \\
I & $10(4.2 \%)$ & $0(0.0 \%)$ & $<0.001$ \\
II & $103(42.9 \%)$ & $9(15.3 \%)$ & \\
III & $116(48.3 \%)$ & $38(64.4 \%)$ & \\
IV & $11(4.6 \%)$ & $12(20.3 \%)$ & \\
\hline
\end{tabular}

ASA American Society of Anesthesiologists

Minor deviations between total number of patients in categories compared to number alive or dead are due to missing data. Missing data are assumed to be completely at random 

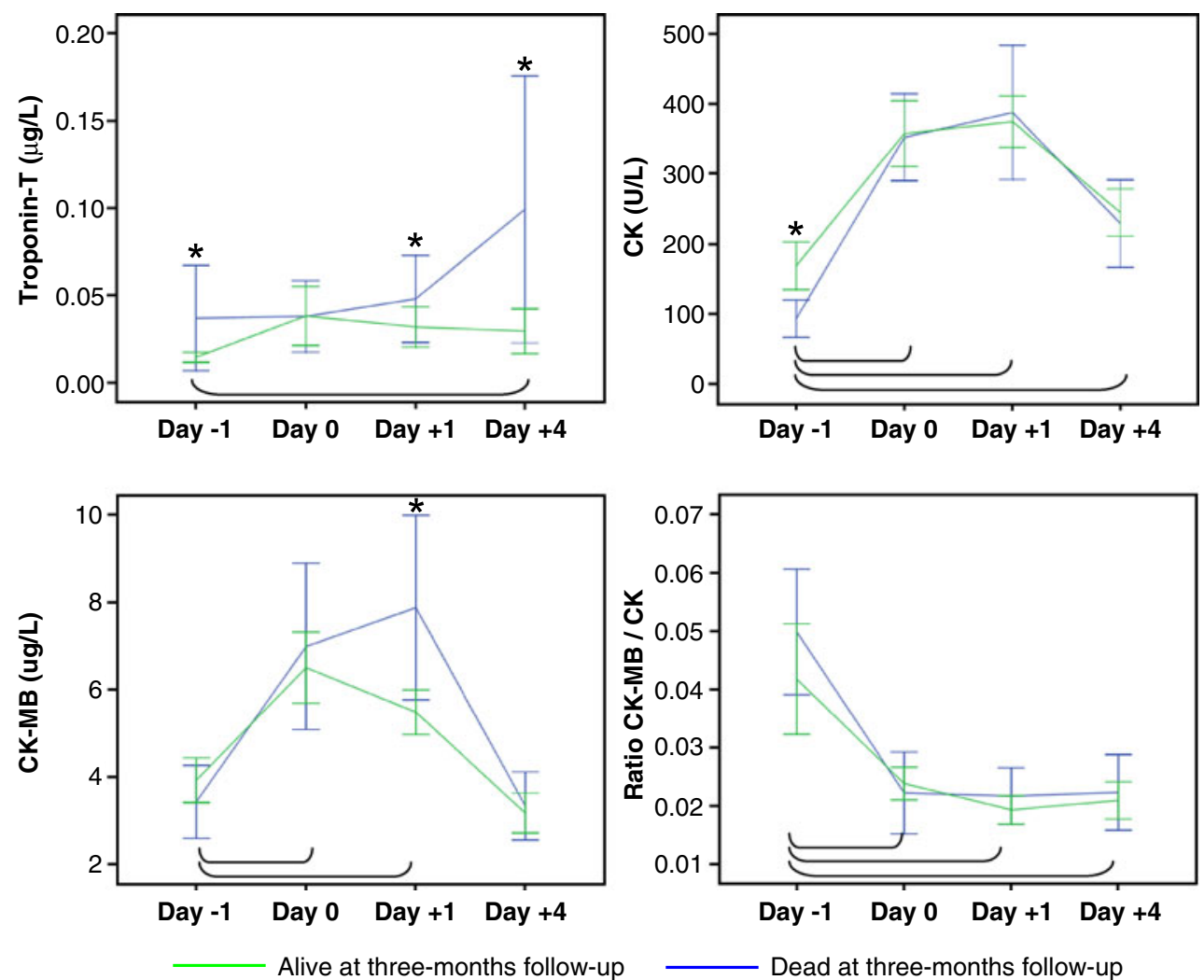

Fig. 1 Mean and 95\% confidence intervals for troponin $\mathrm{T}$, creatine kinase (CK), myocardium-specific creatine kinase (CK-MB) and ratio of CK-MB to CK before surgery, perioperatively and 1 and 4 days after surgery for 3-month mortality. Statistical significance $(p<0.05)$ between mortality groups is indicated by an asterisk. Statistically

The TnT plasma concentrations were split into three equal-sized data subsets, i.e. $\leq 0.01,0.01-0.04$ and $>0.04 \mu \mathrm{g} / \mathrm{l}$, and the ratios of CK-MB to CK concentrations were split into two equal-sized data subsets, i.e. below and above 0.02 . They were analysed for mortality association. Univariate logistic regression analyses showed that plasma concentrations above $0.04 \mu \mathrm{g} / 1$ before surgery correlated with three month mortality [odds ratio (OR) 10.9, 95\% confidence interval (CI) 2.2-54.0, $p=0.003$ ] (Table 2). Stepwise multivariate logistic regression with age, sex, ASA category, levels of TnT and ratio of CK-MB to CK concentrations were performed. High TnT plasma concentration was associated with increased mortality (OR 6.1 95\% CI 6-23.1, $p=0.008$ ) at day four after surgery. No statistically significant association was found for the ratio of $\mathrm{CK}-\mathrm{MB}$ to $\mathrm{CK}$ during the entire sampling period when adjusted for age, sex and ASA (Table 3). Similar regression analyses were done for CK and CK-MB. On day +1 , the CK-MB was associated with mortality (OR 1.1, 95\% CI $1.02-1.2, p=0.012)$. We found that our hypothesis, stating no predictive value from cardio-muscular plasma enzymes significant $(p<0.05)$ differences between before surgery and during follow-up are indicated by the connecting lines. Day - 11 day before surgery, day 0 within $24 \mathrm{~h}$ after the operation, day $+124-48 \mathrm{~h}$ postoperatively, day +44 days after surgery

with regard to early mortality in patients with hip fracture, was false.

\section{Discussion}

This prospective study on 302 elderly patients with hip fracture disclosed that $19.5 \%$ had died within three months. Preoperatively obtained basic patient information was shown to be of particular importance to assess the risk of postoperative mortality. ASA score on comorbidity, male sex and age correlated significantly with three month mortality, also described by other investigators [17-19].

Autopsy studies have shown that cardiovascular events are the main cause of death after hip fracture surgery [20, 21]. Autopsies are rarely done today and the direct cause of postoperative death has not been possible to establish in this or in other recently conducted studies.

In the elderly perioperative myocardial ischaemia is often clinically silent, without haemodynamic or notable ECG changes [22-25]. Over the years, biochemical plasma 
Table 2 Results from univariate logistic regression models predicting 3-month mortality (death)

\begin{tabular}{|c|c|c|c|}
\hline \multicolumn{2}{|l|}{ Variables } & Unadjusted OR $(95 \% \mathrm{CI})$ & $p$ values \\
\hline \multicolumn{2}{|l|}{ Age } & $1.1(1.0-1.1)$ & 0.004 \\
\hline \multicolumn{2}{|l|}{ If male } & $2.4(1.3-4.4)$ & 0.006 \\
\hline \multicolumn{2}{|l|}{ ASA } & $3.7(2.2-6.1)$ & $<0.001$ \\
\hline \multicolumn{4}{|c|}{ If $\mathrm{CK}-\mathrm{MB} / \mathrm{CK}>0.02$} \\
\hline \multicolumn{2}{|l|}{ Day -1} & $1.6(0.8-3.4)$ & 0.225 \\
\hline \multicolumn{2}{|l|}{ Day 0} & $0.7(0.3-1.6)$ & 0.413 \\
\hline \multicolumn{2}{|l|}{ Day +1} & $1.5(0.8-2.9)$ & 0.239 \\
\hline \multicolumn{2}{|l|}{ Day +4} & $1.2(0.6-2.4)$ & 0.620 \\
\hline \multicolumn{4}{|l|}{$\operatorname{TnT}$} \\
\hline \multirow[t]{4}{*}{ Day -1} & $\leq 0.01$ & 1.0 (reference) & \\
\hline & $0.01-0.04$ & $1.5(0.4-6.0)$ & 0.532 \\
\hline & $>0.04$ & $11.0(2.2-54.6)$ & 0.003 \\
\hline & $\leq 0.01$ & 1.0 (reference) & \\
\hline \multirow[t]{3}{*}{ Day 0} & $0.01-0.04$ & $1.5(0.4-5.4)$ & 0.556 \\
\hline & $>0.04$ & $2.9(0.7-11.0)$ & 0.127 \\
\hline & $\leq 0.01$ & 1.0 (reference) & \\
\hline \multirow[t]{3}{*}{ Day +1} & $0.01-0.04$ & $1.6(0.4-7.4)$ & 0.512 \\
\hline & $>0.04$ & $6.0(1.7-21.1)$ & 0.005 \\
\hline & $\leq 0.01$ & 1.0 (reference) & \\
\hline \multirow[t]{2}{*}{ Day +4} & $0.01-0.04$ & $3.3(0.7-15.0)$ & 0.126 \\
\hline & $>0.04$ & $7.0(1.9-25.6)$ & 0.003 \\
\hline
\end{tabular}

$O R$ odds ratio, $C I$ confidence interval, $A S A$ American Society of Anesthesiologists, $C K-M B / C K$ ratio of myocardium-specific creatine kinase to creatine kinase, day -11 day before surgery, day 0 within $24 \mathrm{~h}$ after surgery, day $+124-48 \mathrm{~h}$ postoperatively, day +44 days after surgery

markers have been used to distinguish myocardial injury from skeletal muscle damage, an approach also adopted in this study. CK, reflecting the general skeletal muscle trauma, increased perioperatively. This finding is in line with a recent study in elective hip replacement surgery [26]. Potential heart muscle damage was investigated in this study with CK-MB and TnT analyses. We found small and inconsistent differences for CK and CK-MB plasma levels between those who died and those who survived. The ratio of CK-MB to CK was decreased from hospital admission (day -1 ) to day 0 and stabilised, indicating that skeletal muscle damage dominated and that any myocardial injury remained undetected. Logistic regression analyses showed no correlation with postoperative mortality. This analysis suggests that CK and CKMB are unspecific enzymes that are not distinct for skeletal and cardiac muscle damage following a hip fracture and are not feasible as prognostic markers of mortality, a finding consistent with other investigators [27].

Release of troponins into the circulation is considered to specifically reflect cardiac injury [28]. In our study we analysed $\mathrm{TnT}$ and found that the plasma concentration was significantly higher on the fourth postoperative day in patients that subsequently died compared to those who were alive. Patients with TnT levels above $0.04 \mu \mathrm{g} / \mathrm{l}$ had a six times higher risk of dying vs those with normal plasma levels. This calculation was robust when correction was done for age, sex and comorbidity (ASA score). These results fit with other reports that showed a second wave of troponin elevation several days after surgery which correlated with postoperative mortality [13, 29].

In summary, this study showed that basic clinical information on sex, age and comorbidity (ASA score) and a high postoperative plasma concentration of TnT $>0.04 \mu \mathrm{g} / \mathrm{l}$ are robust predictors of three month postoperative mortality in the elderly undergoing hip fracture surgery. This information may be of importance for therapeutic and post-hospital health care intervention.

Table 3 Results from multivariate stepwise logistic regression models predicting 3-month mortality (death)

\begin{tabular}{|c|c|c|c|c|c|c|c|c|}
\hline \multirow[t]{2}{*}{ Variables } & \multicolumn{2}{|l|}{ Day -1} & \multicolumn{2}{|l|}{ Day 0} & \multicolumn{2}{|l|}{ Day +1} & \multicolumn{2}{|l|}{ Day +4} \\
\hline & $\begin{array}{l}\text { Adjusted OR } \\
(95 \% \mathrm{CI})\end{array}$ & $p$ values & $\begin{array}{l}\text { Adjusted OR } \\
(95 \% \mathrm{CI})\end{array}$ & $p$ values & $\begin{array}{l}\text { Adjusted OR } \\
(95 \% \mathrm{CI})\end{array}$ & $p$ values & $\begin{array}{l}\text { Adjusted OR } \\
(95 \% \mathrm{CI})\end{array}$ & $p$ values \\
\hline Age & $1.1(1.0-1.2)$ & 0.006 & $1.1(1.0-1.2)$ & 0.006 & $1.1(1.0-1.2)$ & 0.001 & $1.1(1.0-1.2)$ & 0.027 \\
\hline If male & $2.4(1.2-4.6)$ & 0.013 & $2.4(1.2-4.6$ & 0.013 & $2.7(1.4-5.1)$ & 0.002 & - & \\
\hline ASA & $3.3(2.0-5.6)$ & $<0.001$ & $3.3(2.0-5.6)$ & $<0.001$ & - & & - & \\
\hline CK-MB/CK & - & & - & & - & & - & \\
\hline \multicolumn{9}{|l|}{$\mathrm{TnT}$} \\
\hline$\leq 0.01$ & - & & - & & - & & 1.0 (reference) & - \\
\hline $0.01-0.04$ & - & & - & & - & & $1.9(0.4-9.4)$ & 0.450 \\
\hline$>0.04$ & - & & - & & - & & $6.1(1.6-23.1)$ & 0.008 \\
\hline
\end{tabular}

$O R$ odds ratio, $C I$ confidence interval, $A S A$ American Society of Anesthesiologists, $C K-M B / C K$ ratio of myocardium-specific creatine kinase to creatine kinase, day -11 day before surgery, day 0 within $24 \mathrm{~h}$ after surgery, day $+124-48 \mathrm{~h}$ postoperatively, day +44 days after surgery 
Acknowledgement The authors want to thank the two orthopaedic department chiefs Tore Kristiansen and Amund Rudlang who have organised all local logistics and eagerly participated in all investigator meetings. We further want to thank Yvonne Bell, Eli Lundemo Øieren and Tor Arne Valle for their assistance and help with study practicalities, which have been of great importance for the team. Finally, the contribution of our database engineer, Vladimir Milic, has been crucial for this work.

Conflict of interest The authors declare that they have no conflict of interest.

Open Access This article is distributed under the terms of the Creative Commons Attribution Noncommercial License which permits any noncommercial use, distribution, and reproduction in any medium, provided the original author(s) and source are credited.

\section{References}

1. Bjørgul K, Reikerås $O$ (2007) Incidence of hip fracture in southeastern Norway: a study of 1,730 cervical and trochanteric fractures. Int Orthop 31(5):665-669

2. Haentjens P, Magaziner J, Colón-Emeric CS, Vanderschueren D, Milisen K, Velkeniers B, Boonen S (2010) Meta-analysis: excess mortality after hip fracture among older women and men. Ann Intern Med 152(6):380-390

3. Abrahamsen B, van Staa T, Ariely R, Olson M, Cooper C (2009) Excess mortality following hip fracture: a systematic epidemiological review. Osteoporos Int 20(10):1633-1650

4. Hagino T, Sato E, Tonotsuka H, Ochiai S, Tokai M, Hamada Y (2006) Prediction of ambulation prognosis in the elderly after hip fracture. Int Orthop 30(5):315-319

5. Carretta E, Bochicchio V, Rucci P, Fabbri G, Laus M, Fantini MP (2010) Hip fracture: effectiveness of early surgery to prevent 30day mortality. Int Orthop. doi:101007/s00264-010-1004-x

6. Nettleman MD, Alsip J, Schrader M, Schulte M (1996) Predictors of mortality after acute hip fracture. J Gen Intern Med 11(12):765-767

7. Lucreziotti S, Foroni C, Fiorentini C (2002) Perioperative myocardial infarction in noncardiac surgery: the diagnostic and prognostic role of cardiac troponins. J Intern Med 252(1):11-20

8. el Allaf M, Chapelle JP, el Allaf D, Adam A, Faymonville ME, Laurent P, Heusghem C (1986) Differentiating muscle damage from myocardial injury by means of the serum creatine kinase (CK) isoenzyme MB mass measurement/total CK activity ratio. Clin Chem 32(2):291-295

9. Wolfson D, Lindberg E, Su L, Farber SJ, Dubin SB (1991) Three rapid immunoassays for the determination of creatine kinase MB: an analytical, clinical, and interpretive evaluation. Am Heart J 122 (4 Pt 1):958-964

10. Fisher AA, Southcott EN, Goh SL, Srikusalanukul W, Hickman PE, Davis MW, Potter JM, Budge MM, Smith PN (2008) Elevated serum cardiac troponin I in older patients with hip fracture: incidence and prognostic significance. Arch Orthop Trauma Surg 128(10):1073-1079

11. Kim LJ, Martinez EA, Faraday N, Dorman T, Fleisher LA, Perler BA, Williams GM, Chan D, Pronovost PJ (2002) Cardiac troponin I predicts short-term mortality in vascular surgery patients. Circulation 106(18):2366-2371

12. Alpert JS, Thygesen K (2007) A new global definition of myocardial infarction for the 21st century. Pol Arch Med Wewn 117(11-12):485-486
13. Chong C, Lam Q, Ryan J, Sinnappu R, Lim WK (2009) Impact of troponin I on long term mortality after emergency orthopaedic surgery in older patients. Intern Med J. doi:10.111/j14455994.2009.02063.x

14. Chong CP, Lam QT, Ryan JE, Sinnappu RN, Lim WK (2009) Incidence of post-operative troponin I rises and 1-year mortality after emergency orthopaedic surgery in older patients. Age Ageing 38(2): $168-174$

15. Nesher N, Alghamdi AA, Singh SK, Sever JY, Christakis GT, Goldman BS, Cohen GN, Moussa F, Fremes SE (2008) Troponin after cardiac surgery: a predictor or a phenomenon? Ann Thorac Surg 85(4):1348-1354

16. American Society of Anesthesiologists (1963) New classification of physical status Anesthesiology 24:111

17. Moran CG, Wenn RT, Sikand M, Taylor AM (2005) Early mortality after hip fracture: is delay before surgery important? J Bone Joint Surg Am 87(3):483-489

18. Paksima N, Koval KJ, Aharanoff G, Walsh M, Kubiak EN, Zuckerman JD, Egol KA (2008) Predictors of mortality after hip fracture: a 10-year prospective study. Bull NYU Hosp Jt Dis 66 (2): $111-117$

19. Verbeek DO, Ponsen KJ, Goslings JC, Heetveld MJ (2008) Effect of surgical delay on outcome in hip fracture patients: a retrospective multivariate analysis of 192 patients. Int Orthop 32 (1):13-18

20. Bergqvist D, Fredin H (1991) Pulmonary embolism and mortality in patients with fractured hips - a prospective consecutive series. Eur J Surg 157(10):571-574

21. Gruber UF (1985) Prevention of fatal pulmonary embolism in patients with fractures of the neck of the femur. Surg Gynecol Obstet 161(1):37-42

22. Mangano DT, Browner WS, Hollenberg M, London MJ, Tubau JF, Tateo IM (1990) Association of perioperative myocardial ischemia with cardiac morbidity and mortality in men undergoing noncardiac surgery. The Study of Perioperative Ischemia Research Group. N Engl J Med 323(26):1781-1788

23. Mangano DT, Hollenberg M, Fegert G, Meyer ML, London MJ, Tubau JF, Krupski WC (1991) Perioperative myocardial ischemia in patients undergoing noncardiac surgery-I: incidence and severity during the 4 day perioperative period. The Study of Perioperative Ischemia (SPI) Research Group. J Am Coll Cardiol 17(4):843-850

24. Wukich DK, Callaghan JJ, Graeber GM, Martyak T, Lyon JJ (1989) Operative treatment of acute hip fractures: its effect on serum creatine kinase, lactate dehydrogenase and their isoenzymes. J Trauma 29(3):375-379

25. Wukich DK, Callaghan JJ, Graeber GM, Martyak T, Savory CG, Lyon JJ (1989) Cardiac isoenzyme values after total joint arthroplasty. Clin Orthop Relat Res 242:232-240

26. Cohen RG, Katz JA, Skrepnik NV (2009) The relationship between skeletal muscle serum markers and primary THA: a pilot study. Clin Orthop Relat Res 467(7):1747-1752

27. Chedrawy E, Hall R, Nedelcu V (1997) Postoperative elevation of creatine kinase (CK-MB): does it contribute to diagnosis of myocardial infarction? Can J Anaesth 44(8):843-848

28. Zethelius B, Johnston N, Venge P (2006) Troponin I as a predictor of coronary heart disease and mortality in 70-year-old men: a community-based cohort study. Circulation 113 (8):1071-1078

29. Ausset S, Minville V, Marquis C, Fourcade O, Rosencher N, Benhamou D, Auroy Y (2009) Postoperative myocardial damages after hip fracture repair are frequent and associated with a poor cardiac outcome: a three-hospital study. Age Ageing 38(4):473476 